\title{
The Silent Hat: Islam, Female Labor, and the Political Economy of the Headscarf Debate
}

hile preparing for the landmark 1910 Edinburgh Missionary Conference that was to initiate the modern Protestant ecumenical movement, Samuel Zwemer, the tireless "Apostle to Islam," as he was nicknamed in the Protestant missionary circle (Wilson 1952) wrote in the preface to his colleague Marshall Broomhall's book, "the accessible Moslem population of China is larger than the Moslem population of Egypt, Persia, or Arabia; and yet practically nothing has been done for them.... The critical hour is at hand when Moslem mission in China must be faced, and specialists set to work to win this great neglected class for the Christ" (in Mott, Beach, and Zwemer 1910, ix-x). Indeed, perhaps as a tribute to this ambitious proposal, Broomhall's book, published in the same year, was titled Islam in China: A Neglected Problem (1910).

Zwemer's commitment to "win this great neglected class for the Christ" went far beyond lip service. In 1933, accompanied by his equally devoted missionary son-in-law Claude L. Pickens Jr., Zwemer trekked the rugged terrain of northwest China in search of the Muslims, among whom he hoped to sow the seeds of the gospel. The trip produced something remarkable and profound: a rich archive of notes, images, and pamphlets, suffused with curiosities and bewilderments, still fresh with their power to captivate after eighty years. One image taken on the fertile Wuzhong plain in Ningxia portrays a young Hui Muslim woman, mounted on a donkey, traversing the narrow dirt path by a rice paddy (see fig. 1). Rein in hands, she sits well balanced on the back of the beast. She might even be pregnant, if the bump is not an optical illusion wrought on her dress by a gentle breeze. "Off for a visit," the caption reads. What is most eye-catching and might have been the reason for the production of this image is the head cover she wears: presumably a black

My special thanks go to Ma Jianfu of Northern University of Nationalities in China. His long-term fieldwork in northwest China, his sensitivity to the issue of gender, and his unreserved generosity in sharing his own findings has helped me greatly in clarifying the arguments in this article. Zhan Yang has read through an early draft of this article and offered invaluable suggestions. My fieldwork was made possible by generous funding from the Wenner-Gren Foundation for Anthropological Research, the Social Science Research Council, the Department of Anthropology at Columbia University, and the Leverhulme Trust (UK). I thank them for their unwavering support.

[Signs: Journal of Women in Culture and Society 2017, vol. 42, no. 3]

(c) 2017 by The University of Chicago. All rights reserved. 0097-9740/2017/4203-0012\$10.00 


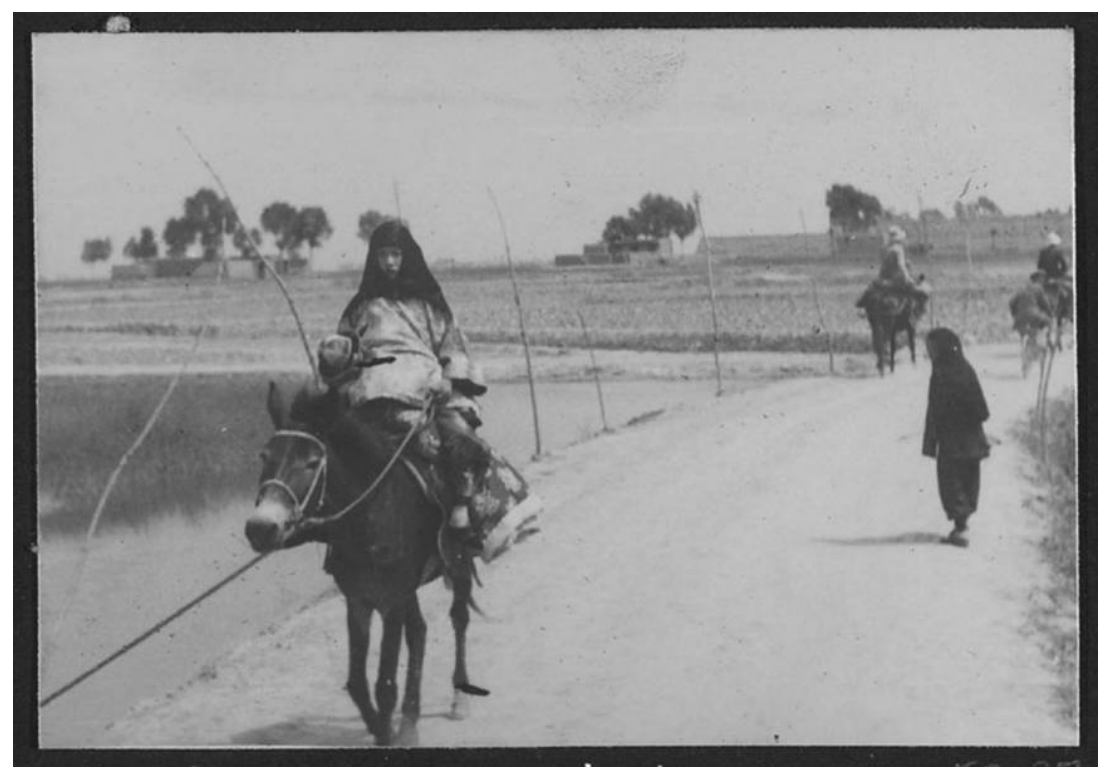

Figure 1 “Off for a visit,” Claude L. Pickens Jr., 1936, Wuzhong, Ningxia, northwest China. Courtesy of Harvard-Yenching Library of the Harvard College Library, Harvard University.

scarf, neatly fit to the outline of her skull and tightly pinned down the chin, covering her ears and neck and leaving only her face showing.

The missionary team had a sustained interest in what they called the "headgears" of the local Muslim women. In another portrait, this one shot in the nearby Gansu Province, a middle-aged Muslim woman in tattered clothes is captured in the frame, with the caption saying she is a "caretaker" at the local gongbei (Arabic: qubba), or shrine, of a Sufi saint (see fig. 2). Maybe it was warm (the shadows indicate noon on a sunny day), maybe the thread buttons on the collar had long fallen off, or maybe she barely realized she was being "captured" by a camera operated by a male gaze. The ragged cotton coat hangs loosely on her skinny body, her neck fully exposed. Rather than a headscarf, she wears a light-colored cylindrical hat that leaves her ears uncovered; they are adorned with gold rings, likely from her dowry when she was married off by her family years before.

The variety of Hui Muslim women's "headgear" far surpassed what Zwemer and Pickens observed on their journey. At the time when these pictures were taken and documented, upper-class elite Hui families were being ushered into the age of modern photography. Rather than being passively captured, they actively posed for the camera. A photo from a wedding ceremony of an influential Sufi family (fig. 3) shows the brides dressed in the 


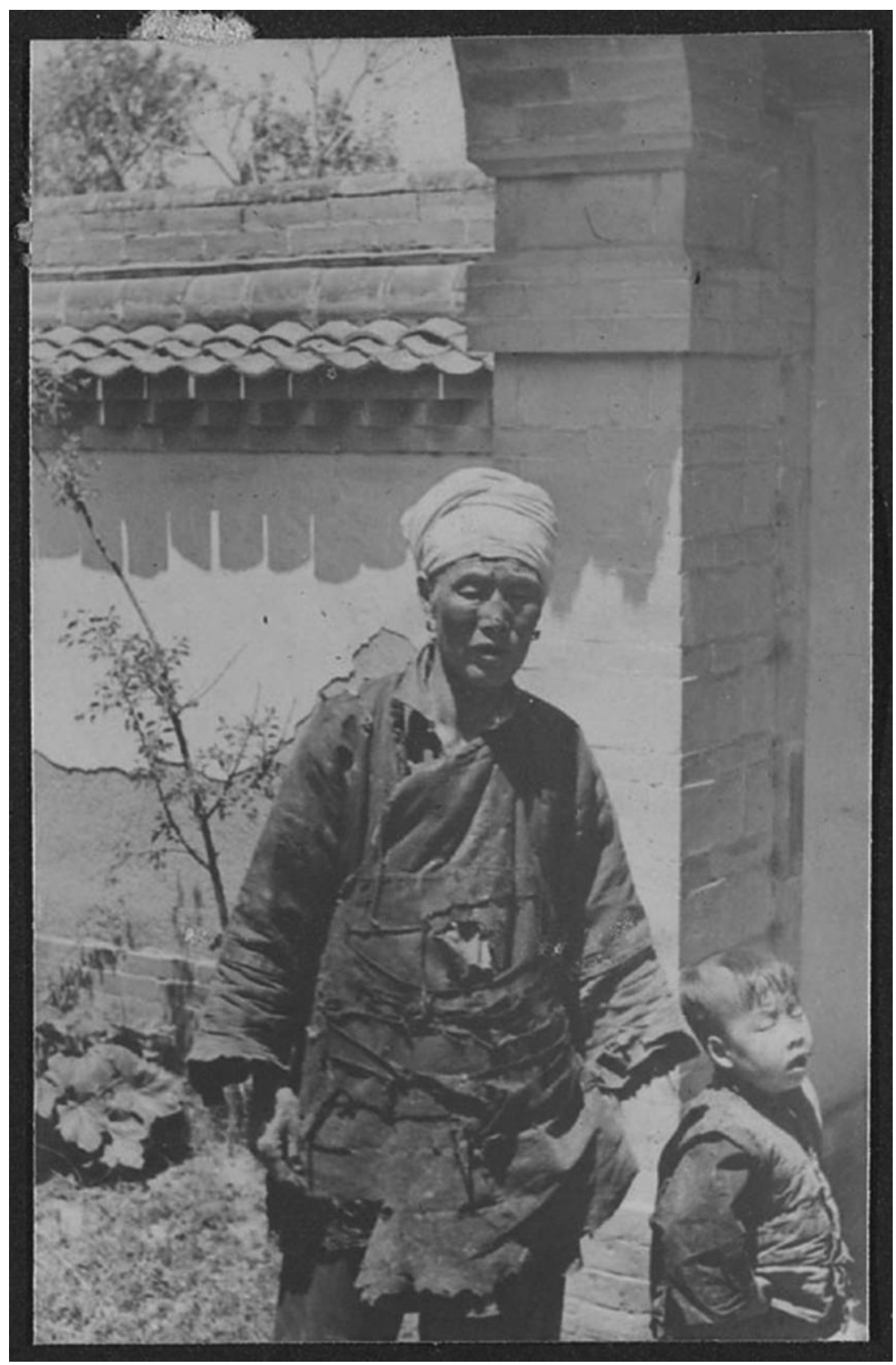

Figure 2 "Caretaker at kumpei of Ma Sung-teh," Claude L. Pickens Jr., 1936, Ankou, Gansu Province, northwest China. Courtesy of Harvard-Yenching Library of the Harvard College Library, Harvard University.

This content downloaded from 195.195.176.005 on June 07, 2019 01:38:27 AM All use subject to University of Chicago Press Terms and Conditions (http://www.journals.uchicago.edu/t-and-c). 


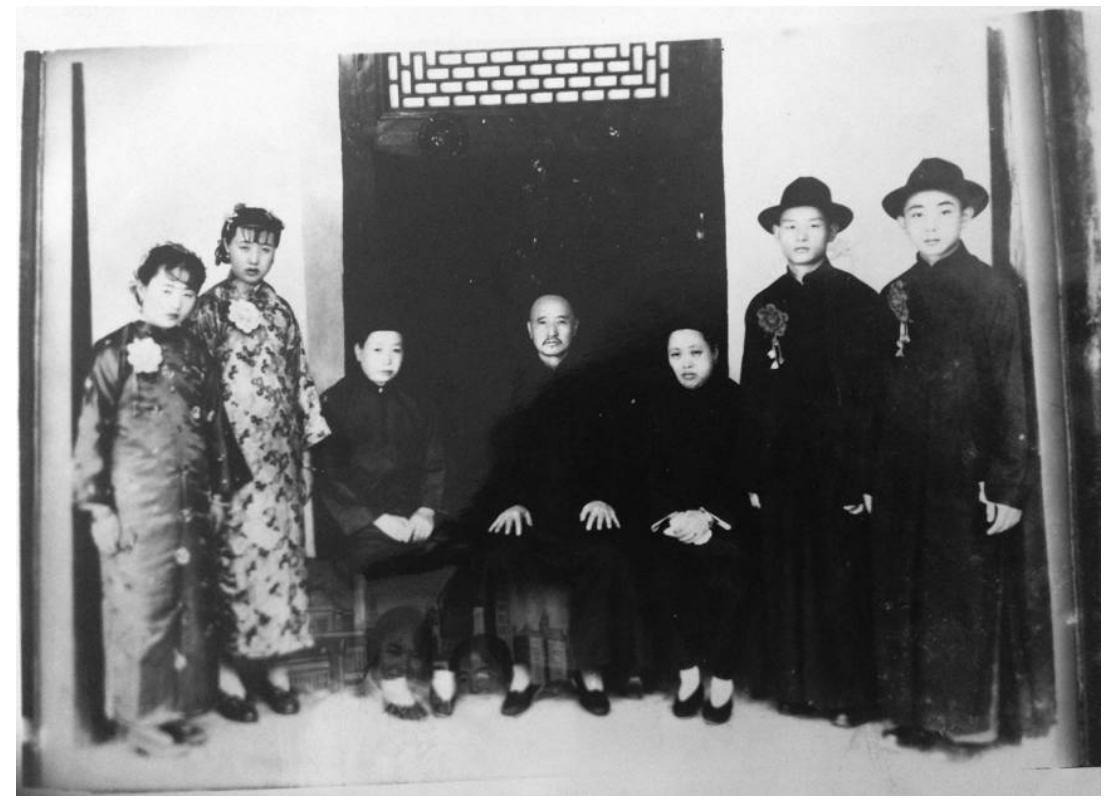

Figure 3 Wedding of an elite Sufi family, author's personal collection. Photographer unknown.

latest fashion of the day, an elegant and stylish cheongsam, or qipao, a type of one-piece gown that bespoke a distinctly upper-class status in the Republican period (1911-49). The fine silky apparel worn by the older women seated next to the unmistakable head of the household reflects the bright light that shines into the room. Neither of the two mothers-in-law has bound feet, though Hui women were no more exempt from this custom than their Han sisters in imperial times. And none of the women have their hair covered; the young brides wear floral accessories, and the light fringe cut of their hair puts them in line with trendsetting ladies strolling the streets of metropolitan Shanghai.

\section{The veil, again}

What is the point of revisiting Muslim women's head wear-whether and how they cover their hair - when this topic has already been extensively discussed by critical theorists across a wide range of national and transnational contexts? ${ }^{1}$ It is not only academics who might be weary of this attempt. "I

\footnotetext{
${ }^{1}$ A large body of literature has been published in this regard. Apart from those that will be discussed in more detail below, other works include El-Guindi (1999), Çinar (2008), Heath (2008), Gabriel and Hannan (2011), Behiery (2012), Celik (2012), Elver (2012), Stehle
} 
lament that so much energy has been tied up into worry about what women wear," writes Pamela Taylor (2008, 123), cofounder of Muslims for Progressive Values in the United States. "Mostly, I don't think about hijab," she says, "I worry about war, about women living in the shadow of oppressive regimes, about poverty and hunger, about unfair laws and wasted lives. ... The hijab is, after all, just a scrap of cloth - a politically and emotionally charged scrap of cloth, but an article of clothing nonetheless. My energies are better spent making this world a kinder, safer, and more just place for all people" (128). ${ }^{2}$

Taylor's message conveys more than she realizes, as a matter of fact, for indeed there are Muslim women in the world for whom the veil is literally "a scrap of cloth." Many Muslim women living in parts of rural northwest China, for instance, have to consider carefully the frequency with which they wash their head covers. Grueling agricultural labor not only exhausts their illnourished bodies, but sweat and the fine yellowish gray dirt from the Loess Plateau (Huangtu Gaoyuan) also soil their headscarves and hats in a matter of minutes. The little water their families are able to save is carefully guarded for Islamic ritual ablution, often prioritized above daily drinking needs. Showers are rare, and laundry, when it is done at all, seldom uses clean water. For these Muslim women, the material character of the veil- that it is "a scrap of cloth" susceptible to easy pollution and in need of constant care-is so significant that they cannot afford to ignore it. When Taylor is throwing her hijāb into a washing machine while doing her weekly laundry, a young Muslim woman in northwest China may be scratching her head trying to figure out where she can get the water to wash her soiled veil or how she can prevent it from getting dirty again during the next day's labor.

This is certainly not to belittle Taylor's ambition to fight for social justice. The particularity of her predicament invites not so much a criticism of the parochialism of first-world Muslim feminists as it does an ethnographically grounded examination of how transnational political economy organizes the terms and discourses through which issues of Muslim women's head coverings are spoken of. Signifiers, either such apparently trivial daily expressions as "scrap of cloth" or grander claims about women's agency in the Islamic revival (Mahmood 2001, 2005), do not simply point to their signifieds

(2012), Özcan (2013), Gökarıksel and Secor (2014), and Selby (2014). The list of works discussed in this article is certainly not exhaustive.

${ }^{2}$ To be sure, the predicament that Taylor faces goes far beyond this weariness. She also worries that wearing a hijāb will put her in line with male Islamists whose political position she does not concur with $(2008,125)$. She is equally uncomfortable with the possibility that this choice may unwittingly buttress the view that non- hija $\bar{b} b$-wearing Muslim women are necessarily lacking in piety and should not be allowed to speak for Islam (Bucar 2012, 126). 
when they travel transnationally. In the case of the contrast between Taylor and some of my women interlocutors in northwest China, the pragmatics of such signifiers as "scrap of cloth"-what they do or what is done to them rather than what they mean - is deeply embedded in the structural organization and distribution of materialities on a global scale.

During the two periods of my fieldwork in Ningxia and Gansu Provinces in northwest China (September 2011 to August 2012 and late 2014 to the summer of 2015), my questions as to why one veils were almost invariably met by a discomfiting (to me) silence or brief responses such as "because I am married." On the other hand, I was often led into an unexpected and surprisingly rich account of the stylistic shifts of the head cover that scarcely addressed my concerns regarding notions of Islamic piety. While I anticipated that my interlocutors would speak to the headscarf debate, what actually happened in the field was that I was increasingly drawn away from the terms of that debate. As my work gradually deepened, the commonplace treatment of Muslim women's head wear as a sign also acquired a new dimension: that it could become a sign (certainly a heavily disputed and politically loaded one) for some is predicated on the fact that it cannot remain merely a sign for others, and this contrast, as I shall argue in this article, is articulated on a global scale.

By making this argument, I do not mean to simplify the historical complexities that characterize the headscarf debate in a variety of distinct EuroAmerican, Middle Eastern, North African, South Asian, and Southeast Asian contexts. The history of colonialism, racism, and gendered orientalism that continues to structure the perception and regulation of the bija $\bar{b}$ in France gives the French headscarf controversy a different face than that given to the debate in contemporary Algeria. ${ }^{3}$ Similarly, if wearing the hijāb on the campus of an American university can signal solidarity with the Palestinians and a struggle for gender equity, in a different context it could also mean support for gender hierarchy and segregation. It could function as a challenge to sexism and an assertion of gender equality in London, but these "are not meanings that the hijab could possibly have in Cairo or Karachi or Riyadh or Tehran” (Ahmed 2011, 213). Such differences are crucial but not only because they urge us to distinguish between different political configurations that entail distinct pragmatics of the same sign. Perhaps more important, they also compel us to be particularly cautious when drawing comparisons and making arguments that circulate transnationally. In order to situate the intervention of this article more squarely within the current

\footnotetext{
${ }^{3}$ See Killian (2003), Scott (2007), and Bowen (2008, 2010); cf. Korteweg and Yurdakul $(2014,44)$.
} 
feminist debate on Muslim women, particularly to show how I approach the critical issue of difference, let me begin by demonstrating how my argument builds on and differs from that proposed by Saba Mahmood.

For those of us who grew up or have conducted long-term fieldwork in a Muslim environment where contemporary forms of Islamism coexist with other devotional practices such as Sufi collective or dream interpretation, Mahmood's widely acclaimed book Politics of Piety (2005) presents a dilemma perhaps not felt - at least not as intensely — by other feminist academics. On the one hand, it was published at a time when the social and political ravage of Islamophobia was severely aggravated by the global "war on terror." The book emerges as a powerful voice that reorients the understanding of feminist agency and reveals the insidious harm wrought by the hegemony of its liberal conception. It provides a reading of Islamic ethical practice that is equally appealing to the sensibilities of certain strains of Western anthropological and philosophical thought. For some of us, it made a forceful argument at a particularly apt time.

On the other hand, however, it also provokes a sense of unease that gradually materializes into various arguments and struggles intended to articulate what some of us find potentially troubling in Mahmood's book and its enormous impact on later studies of Muslim women. Amina Jamal, for instance, argues that the heavy focus on textual interpretive strategies and the treatment of Islam as a discursive tradition might run the risk of neglecting other forms of ecstatic and mystical practices of Islam that are historically more influential in Pakistan, where she conducted her fieldwork on the women's wing of Jamaat-e-Islami (2013, 6, 35-36). While studying Al-Huda, a Muslim women's social movement in Pakistan that shares much in common with women's mosque groups in Cairo, Sadaf Ahmed grew increasingly uncomfortable with the movement's often exclusivist and puritanical pronouncements and expresses her concern in the form of a series of questions: "Is Pakistani culture ... an exclusive articulation of predefined and preconceived 'Islamic' values, or is it an amalgam of ancient pre-Islamic rites and nonIslamic rituals, Islamic values, modern secular-colonial practices, and postmodern globalizing tendencies? What is it that is keeping us from seeing the advent of Islam on the Indian subcontinent as a foreign import, an act of imperialism, merely our own position of being inside the hegemonic religio-nationalist discourse?" $(2009,186)$.

Perhaps it is precisely because of such questions, the entanglement of contradictory commitments they entail, and the profoundly affective power they command, that Mahmood had to move her field site from Pakistanwhere she had been deeply involved in feminist struggles - to Egypt, where she could presumably keep a distance from similar questions raised among 
Egyptian feminists and academics (Mahmood 2005, xii). ${ }^{4}$ This detached stance enables her to reflect more critically on her previous political position: "The reason progressive leftists like myself have such difficulty recognizing these aspects of Islamic revival movements, I think, owes in part to our profound dis-ease with the appearance of religion outside of the private space of individualized belief" (2005, xi; cf. 189). This much might have been true for Mahmood, but for those of us who study Sufi collectives and dream interpretations, what is alarming in some strains of contemporary Islamism is not so much their "emergence" into the public sphere as the historically specific form of this publicness and its at times aggressive assertion against other Islamic devotional practices. The privatization of Islam is merely one of many contradictory political initiatives of the modern colonial and postcolonial state, and it is very often preceded, crisscrossed, or supplanted by official state support of Islam, a fact well registered by Mahmood. Moreover, for those of us who work on Sufism, the public engagement of Sufi orders is a salient historical fact, and saint veneration and dream interpretation have long been political. What contemporary Islamism changes, in other words, is how Islam figures publicly and politically rather than whether Islam should enter the public sphere (see Jamal 2013, 42-43). By setting a contrast between Cairene pietist women and (Western) secular liberals, Mahmood may be leaving out a great portion of Muslim feminist intellectuals for whom the question is framed in different terms and the politics of public religiosity matters in a different way.

Many of the rural Hui Muslim women discussed in this article were born into Sufi families in Ningxia and Gansu, two provinces in northwest China with a large Muslim population. Their ancestors - both male and femalehad fought courageously either to protect their orders against suspicious emperors or merely to survive in an inhospitable natural environment where prolonged drought was normal. They often participate in collective rituals alongside men, and the preparation of communal dining and distribution of blessed consumables, both crucial for the consummation of the rite, rely heavily upon women's labor contribution. For them, Islam has never been "private," though many still feel uncomfortable with the public assertiveness of some younger urban Muslim women, not the least because they are sometimes criticized by the latter.

\footnotetext{
${ }^{4}$ See Selim (2010) for a critique of Mahmood that reveals similar structural dilemmas in Egypt, hence demonstrating that it is not so much a question of whether a certain place is conducive to a detached and patient labor of thought as it is one of who can afford to occupy a position where the urgency others are forced to feel may not be perceived as so powerful as to constantly prevent the successful enactment of a particular kind of intellectual labor.
} 
This certainly does not mean that rural Hui Muslim women in northwest China do not cherish and cultivate Islamic piety in their daily lives and ritual acts. The point that ethical self-cultivation can take different forms, and that the same norm can be inhabited in contradictory ways, has already been eloquently made by Mahmood, who also shows that even the piety movement itself is marked by internal dissent. The argument I want to make in this article is not merely that such differences exist in the world or that differential positionalities coexist as parallels but rather that these differences are transnationally articulated and distributed on a global scale. This transnational articulation and distribution - the historically specific structural organization of heterogeneities - needs to be seen in tandem with transnational political economy. Between Pamela Taylor and my interlocutors in northwest China is not merely a chasm that separates different, even contrasting, modes of ethical self-cultivation but also an organized international political economy that distributes both religious and politico-economic values around the globe. The difference is not between two or more worlds but within the same world. Focusing on particularistic ontologies and revealing the specific manifestations of concealment in a local context, as is masterfully accomplished by Anjum Alvi (2013), can undoubtedly enrich our knowledge of Muslim women and provide timely caution for our politics, but it also runs the risk of a certain relativism that prevents us from seeing how the world is differentially assembled as much as it is partitioned at the level of ontology. As we have produced an enormous amount of work exploring the latter, perhaps it is time that we begin to think more carefully and critically about the former. It is in this direction that this article hopes to make its intervention.

In the next section, I situate the particular kind of head cover worn by the rural Hui women in northwest China, namely maozi (the "hat" that can be seen in fig. 2), in relation to other Islamic sartorial items donned by younger and often (sub)urban Muslim women. This contrast unfolds not only at the level of clothing styles but also at the level of their discursive representation. While the (sub)urban women who don the more religiously marked gaitou ("head cover," here a conventional designation reserved largely for hijāb) are equipped with a large vocabulary and an abundance of discourse on piety, few of the rural Hui women I interviewed could offer a religious explanation of the maozi that made their narrative assimilable into the headscarf debate as we know it. They fell silent when I probed them on issues that $I$ was interested in and spoke on topics that I initially could hardly make conceptual sense of, such as the many shifts of maozi in its color and fabric over the years. This article results from my ongoing struggle to come to terms with the tension between what I expected to hear and what I was compelled to listen to. 
This discussion is followed by a more detailed ethnographic study of maozi. Through examining its multiple stylistic changes, I will substantiate my argument proposed above by showing that, first, rather than discourses on Islamic piety, narratives of maozi lead us to focus on the issue of women's labor and the vicissitudes of its historical form both in the socialist and in the neoliberal periods. Tracing changes of maozi forces us to follow the politicoeconomic transformations that encompass the world where rural Hui women live rather than how norms of piety are inhabited through the practice of veiling. Second, this tracing also offers us a glimpse of the middle link that makes visible the transnational politico-economic chain that binds my interlocutors in rural Ningxia and Gansu to first-world Muslim feminists such as Pamela Taylor in the United States. The link between rural Muslim women and their urban sisters (particularly women workers), forged by the socialist articulation of female labor power, was severed in the neoliberal period, and this separation, while instituting a sharp urban-rural division, also relegated rural Hui women to an abject position, their maozi ridiculed as a sign of backwardness, lack of aesthetic taste, and more frequently than before, of unIslamic and "customary" practices. From Taylor in the United States to young Muslim women in urban China, on to the rural Hui women in Ningxia and Gansu, the transnational articulation of religious difference needs to be seen as linked to the transnational distribution of values and materialities. If the sign, in this case the heavily disputed Muslim women's veil, cannot be detached from its material quality (Keane 2007, 2013), then this semiotic interest in materiality ought to be inflected by a Marxian analysis of the global political economy that organizes the production and distribution of materialities. As I said above and shall try to show in the following, that the veil could become a sign for some is predicated on the fact that it could not remain merely a sign for others. It is this heterogeneous chain that I hope to flesh out and render visible in this article.

\section{Situating maozi}

The maozi worn by rural Hui women in northwest China could hardly be confused with any conventional headscarf or the "new veil" adopted by Islamist women in the mid-1970s (Macleod 1991, 1992). Since the early 1990 s, it has been increasingly marginalized by the "new veil," as the younger generation of Hui women turn to the latest styles of gaitou that circulate across national borders in conjunction with contemporary Islamist ideologies emanating both from the Gulf states and from Southeast Asia. While aspiring Hui have long pursued Islamic studies at the Islamic University of Madīna, Malaysia has emerged as another attractive location in the past de- 
cade, given its geographical proximity to China and its presumed combination of modernity and Islamic piety. Though many Hui students drop out before graduation to seek a business career, there is nonetheless a steady increase in the number of Islamic clerics and teachers who return to China after the conclusion of their studies.

To be sure, most of these returning students are middle-aged men, passionate about spreading their new message freshly adopted from the "center" of Islam. Schools are founded mostly in suburban areas where land is readily available for purchase and conversion into campuses. Some receive regular donations from the Gulf states, with Saudi Arabia and Kuwait being the two major sources of donors, while others tend to rely entirely on the goodwill of local Muslim entrepreneurs. Many of these schools follow strict rules of gender segregation, and some are established exclusively for girls. That such schools can acquire the land they need is predicated on a general transformation in China's rural areas. In both Ningxia and Gansu, large tracts of farmland have been expropriated by the local governments over the past two decades and put on sale to finance their large-scale construction of local infrastructure. The reapportioning of land for the sake of creating industrial parks (gongye yuan) to invite both domestic and foreign investment has also considerably diminished the amount of land owned by individual peasant families. As we shall see, it is precisely this land policy that has tied some older Hui women - those who still wear the maozi-firmly to agricultural labor in the neoliberal period. The global rise of neoliberalism and its particular incarnation in China have thus both enabled more Hui Muslim men to acquire the financial resources needed to pursue Islamic studies abroad and prepared the economic conditions that give them the social and material space where they can spread their message of piety upon return. At the same time, however, these same conditions also push the rural Hui women who wear the maozi further down the politico-economic and symbolic hierarchy.

Although the "new veil" finds its most palpable presence in these girls' schools, it also spreads rapidly among college students who are eager to reform the Islam in which they were brought up. Discourses about these new gaitou are often built around a newly found religious piety and sense of selffulfillment. Younger Hui women are also more willing to speak about their motivation in veiling. They have the requisite textual and dispositional repertoire to offer an eloquent response to a question such as "what is your view about wearing the gaitou?" Compared to the volubility of these young women, the wearers of maozi were considerably more reticent when I interviewed them with the same question. While the religious connotation of gaitou cuts across generation and marital status, it is only married women 
who wear the maozi. They are often required by their families to put it on upon marriage.

Many studies of Muslim women have relied heavily on interviews in their investigations. Sherifa Zuhur, for instance, in her informative work on young Egyptian muhajabāt (those who wear the hijāb) in the late 1980s, conducted extensive structured and semistructured interviews with fifty Cairene women. It is significant that the "peasant woman (fallaha)" is not included in her sample. "Up to now, the Islamists have not visibly recruited many rural women," although "the situation may change as rural migrants continue to pour into the cities of Egypt" (Zuhur 1992, 9). Nancy Smith-Hefner's rich article on Javanese Muslim women, for another example, also draws its data from "150 in-depth interviews" with primarily middle-class men and women in the central Javanese city of Yogyakarta $\left(2007,391\right.$ n. 3)..$^{5}$ The underlying presumption is often that women would naturally have something to tell the researcher when questioned about their intention in adopting the veil. The persistence of this presumption may have to do with the fact that most of these studies are conducted in an urban context and focus mainly on university students and middle-class Muslim women, for whom the terms of the headscarf debate are often fairly well known. This choice of informants is not surprising, as it is precisely these women who form the core of the female recruits of the Islamic resurgence in many parts of the Muslim world. They are well situated to offer what the anthropologist hopes to gather or expects to hear.

The reverse is true of the women who wear maozi. Though there is real family and neighborhood pressure for women to keep their maozi on, few women voice complaints. The maozi is so pervasive as not to deserve any special attention - it appears unremarkable and is barely noticed. When some younger women do complain, their grumble is less an indictment of male oppression than a worry that the maozi could hardly go with their new outfit. Apart from these, the maozi seldom receives any comment. If the new hijāb possesses the impressive power to circulate across national borders and to elicit interest and discourses across a broad range of political parties and academic interpreters, the maozi seems to be located at the other end of the spectrum: it remains lodged in the rural and suburban areas, drawing little attention from those concerned with more explicitly religious sartorial changes. In contrast to the multifarious and subtle functions of the veil in signaling social relations of intimacy and distance (Abu-Lughod 1986, 1993), the maozi comes across as bearing little flexibility: apart from

\footnotetext{
${ }^{5}$ For other studies that also rely heavily upon interviews, see Ruby (2006), Droogsma (2007), Afshar (2008), O’Neill et al. (2014), and Abbas (2015). For a more critical use of interview as a method of research, see Macleod (1991).
} 
announcing marital status and refusal of sexual invitation, it barely indexes social distance in its infinite degrees of differentiation.

However, if maozi scarcely constitutes a gravitational point around which discourses of piety and practices of intimacy cohere, its stylistic shifts, as we shall see in the next two sections, encode a complex history of women's labor. This very history locates rural Hui women in a position where prolonged discourses about the intimate link between veiling and piety might not be capable of giving voice to their particular female subjectivity, which may be one of the reasons why my Hui women interlocutors seldom resorted to such discourses when they narrated to me the otherwise dense and rich history of maozi. The different positions and the underlining power differentials between them and the urban women pietists, embedded in the heterogeneous transnational political economy, have equally instituted a symbolic economy that distributes words and discourses on a global scale. Both the condition of labor and its representation in Hui women's imagination are reflected in changes to the maozi's color and fabric: while the popularity of a dark hue owes much to the intention to hide the sweat marks resulting from backbreaking field labor in the neoliberal period, for several decades in the socialist period, the white maozi functioned as a hinge that connected rural Hui women to their urban working sisters by way of imagination, thus in part re-presenting their agricultural labor as similar to the politically more honorable industrial labor of the urban proletariat. Maozi might have been a sign all along, but it has never been merely a sign. It covers Hui women's hair and functions to cultivate locally held feminine virtues. But it also absorbs sweat and smell, and its cleaning requires the use of water, which for many rural Hui women in Ningxia and Gansu must be reserved for irrigation and ritual ablution. All this compels us to turn to the history of female labor in northwest China.

\section{Labor's color: The socialist articulation of female labor power}

Mayi was a middle-aged Muslim woman when I met her during my fieldwork in Wuzhong, part of China's Ningxia Hui Autonomous Region. Wrapped in thick layers to counter the severe cold of the freezing Ningxia winter, she sold incense and Islamic accessories in front of a renowned Jahriyya Sufi daotang ("hall of Dao"). Seeing me on a daily basis, she insisted calling me ahong, the Persian word for religious scholar that is widely used among the Hui. Known for her perseverance and extraordinary financial skills, she wielded much power in her family, to the point where her husband was said to be "too weak" to assume the role of the household head. Upon discovering that I was interested in learning about women's maozi, 
her eyes brightened: "I can give you a complete set and show you how they changed over time!" What she gave me the next day was captured in figure 4. Seven maozi of different colors were neatly and carefully laid out, in chronological order from the bottom up. Mayi did not have much to say except that, "I don't have the maozi made of laobaibu ('old white cloth'). That was the earliest. So I only gave you a piece of laobaibu rather than the maozi itself. It was mianbu ('cotton cloth'). Now women don't wear it, because people use

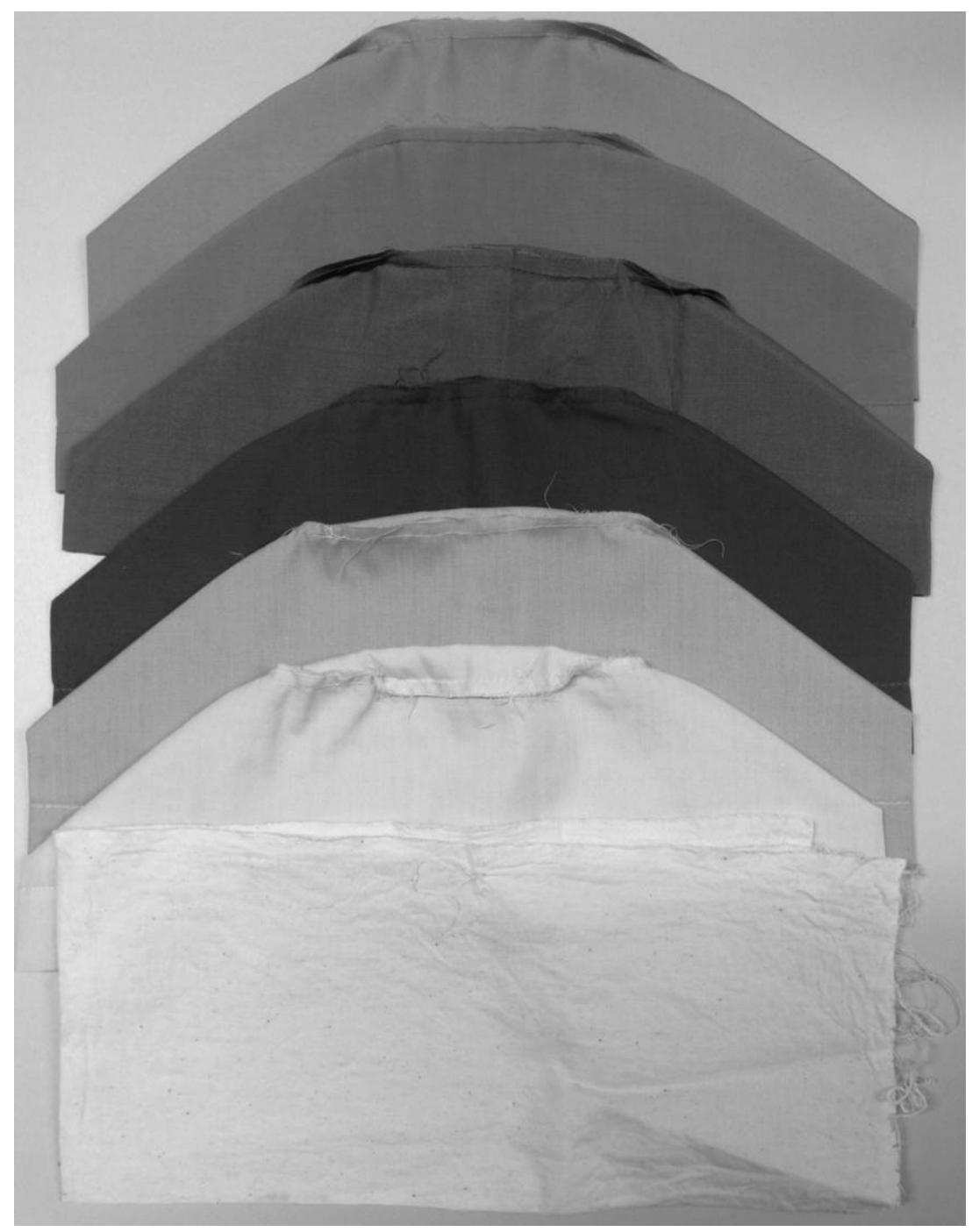

Figure 4 "Labor's Colour." Photo by the author. A color version of this figure is available online. 
laobaibu for xiao ('mourning') clothes. And wearing the maozi of laobaibu is bu jili ('not auspicious'). Besides, some think that it makes you look like a nigu ('Buddhist nun')."

Few of these statements can stand a reality test, in fact: the use of white cotton cloth for mourning clothes is a long-term customary practice that did not prevent its being used for sewing maozi in the past, and many-even most - Buddhist nuns in China wear head covers whose color and style make them easily distinguishable from maozi of laobaibu. However, it is also true that the piece of "old white cloth" says much more than Mayi realized at the time. It is not coincidental that she did not have a maozi ready-made from it. We need to go back to the history of rural women's labor and its twists and turns since the early twentieth century to come to grips with this apparently trivial detail.

Writing in 1939, the distinguished Chinese anthropologist Fei Xiaotong observed that the economic depression of China's rural peasantry was the result of a combination of several factors, the most important being the decline of domestic industry. Through meticulous calculation based on data collected from a rural village in the Yangtze Valley, he suggested that the household production of silk, rather than the plowing of land, contributed the necessary supplement without which the life of the peasant family would be practically unsustainable. However, the forced integration of China into the world capitalist market and the subsequent drop in silk prices sent the rural economy into a deep plunge. This, according to Fei, was the core of the hunger problem facing China's peasantry (1939). What he does not emphasize but what is apparent throughout his detailed ethnography is the fact that it was mainly the rural women who were most heavily hit by a distant world market beyond their reach, since it was they who were the major workforce in household spinning and weaving. The role of women is made clearer in a later essay, though the issue of gender is again overshadowed by the general concern with rural industry: "in my youth I helped my grandmother spin cloth, and among my mother's marriage gifts there was a spinning wheel" (Fei 1953, 114). Although the domestic production of silk was specific to coastal provinces, household spinning and weaving was a common component of rural industry across China. It would not be surprising, therefore, if the earlier maozi were made from homespun cotton cloth, which was often white.

The continual progression of economic collectivization, initiated by the socialist revolution in the late 1940 s, culminated in the nationwide establishment of communes by the end of the 1950s. Rural industry was reorganized, and women's position both within the family and in the local community shifted largely as a result of changes to their labor status. Particularly in 
northwest China, rural women's participation in manual agricultural labor long predated the collective period. From the 1920s to the late 1940s, men working in the field were under constant threat of forced abduction and conscription as a result of the ceaseless wars among local warlords and between the Nationalist Kuomintang and the Communist Party. Many men were always on the run and seldom sent remittances back home, if they survived and managed to find some kind of job. Women, left behind and without much means to get by, were compelled to assume the role of the main breadwinner for the patrilineal stem family. They were not offered the "luxury" of seclusion, although some may have held female domestic confinement as a norm to aspire to. The attraction of the cultural norm is here augmented by its more explicit association with class status. As Elizabeth Croll points out, "if ideally women did one [household affairs] and abstain from the other [public spheres], it was the prerogative of the richer classes to live up to these norms. Among the poor, economic factors interceded to a greater or lesser degree to modify these standards in practice" (Croll 1978, 15; see also Hershatter 2011).

Rather than a complete break from the past, what collectivization brought about was a reorganization of women's labor both in and outside the domestic sphere. A similar structural division of labor was preserved, however. Many men were sent out by their collectives for nonagricultural sideline jobs or other paid employment to earn cash for the commune, and women continued to be responsible for the bulk of agricultural work (Hershatter $2011,130)$. The decline of women's domestic handicrafts - the spinning and weaving that used to occur primarily within the household - was only the predictable consequence of the nationalization of the economy and the strict restrictions imposed on market exchange. At this point, Hui Muslim women not only did not purchase ready-made maozi from the market, they could not even make the cloth in their private chambers. As a result of collectivization, they relied exclusively on state distribution for the acquisition of basic industrial products. Even if they continued to spin and weave, they spun and wove not for their own consumption. They worked for the state and received their share from the state; both production and consumption were mediated by the public organization of labor power. Again, maozi was not a commodity to be purchased ready-made from the market, but now even the cloth itself was subject to uniform state distribution. So it is completely understandable that Mayi did not have a maozi made from laobaibu: the "old white cloth" came in only as raw material and never in the completed shape of maozi. The last step only occurred in the household, and by means of women's manual labor under the dim light of a kerosene lamp. 
The socialist reorganization of labor power at the national level and its differential institution of distinct labor regimes in the rural and urban areas also created a new scheme of representation in which Hui Muslim women's maozi began to acquire a new value. Even more significant, this new scheme was also modeled on the grammar of female labor. The fact that rural Hui women could only rely on the state for the redistribution of industrially produced cloth for their maozi points us to the highly gendered textile factories where such cloth was mass-produced by their urban sisters. Hailing both from urban residential quarters and from suburban and rural areas through strictly regulated labor migration regimes, these women workers also wore maozi $i$ of almost the same style as that worn by the Hui women but as part of their uniform - that were made from the same type of cloth they themselves produced on the machinery.

To be sure, this did not mean that a more immediate relationship existed between the labor power of urban women textile workers and the products of their labor. Both this relationship and that between rural Hui women and their maozi were mediated by the socialist collective organization of labor power. There was in fact a higher-order relationship of mutual mediation between these two relationships: on the one hand, rural Hui Muslim women, by engaging in heavy agricultural labor, produced the necessary staple crops that were vital to the ration system that sustained the reproduction of female labor power in the urban textile factory. The labor of rural Muslim women, in other words, functioned to mediate the seemingly immediate relationship between the spindle and the hands of urban women workers. On the other hand, as we have already seen, while they contributed to the reproduction of urban labor power, rural Hui women also relied exclusively on their sister textile workers in state factories for the production of the cloth that made their maozi. If it was labor power that was reproduced in the city, it was largely a patriarchal symbolic order that was reproduced in the countryside, and this dual reproduction across great distances hinged upon the differential articulation of two distinct forms of female labor: that of the rural women peasants and that of the urban women textile workers.

It is in relation to this complex labor regime that we need to situate the representational value of Hui Muslim women's maozi during this period. As industrialization gradually spread, particularly until the end of the 1970s, when neoliberal reform was at the doorstep, rural Hui women's maozi began to share the same material and color as that worn by urban textile workers. The more or less natural yellowish white gave way to a bleached snow-white. The industrial touch was brought about by a change in fabric as well-rather than pure cotton, maozi was now manufactured with polyester, known in Chinese as diqueliang, or "truly cool." This by-no-means coincidental conver- 
gence endowed the maozi with a new meaning. Rural Hui Muslim women were now able to align their own labor with that of their urban sister workers whose form of labor straddled two models, both propagated by the state: they were members of the urban proletariat, and they were engaged in a quintessentially feminine form of labor. ${ }^{6}$ The shifting of the labor context from the rural to the urban, as a result of the socialist collectivization of industrial production, did not change the gendered meaning of spinning and weaving, either by hand or by modern machinery. While rural Hui women were separated from their urban sister workers at the level of relations of production, they were joined at the level of consumption by the tenuous yet significant imaginary rendered possible by the sharing of the same kind of maozi. During the socialist period, the wide circulation of images of the urban woman textile worker, wearing the white maozi and busying herself with the mechanical loom, reinforced this imaginary link and made it all the more alluring for rural Muslim women. With the onset of the 1980s, the new maozi circulated in the market, this time ready-made perhaps for the first time in history, with other fashionable clothing and accessories that were also fabricated with "truly cool."

\section{Specters of neoliberalism}

As the economic reform continued in the 1990s, perhaps not surprisingly the structural articulation between urban and rural women laborers seen in the socialist period began to unravel as well. Maozi began to have its own fashion, too. ${ }^{7}$ A touch of light lavender blue was added to the dye, and no one seemed to know why or how this happened initially. Some Hui women simply said this "looks nicer" without being able to explain why it was blue rather than another color that made the maozi nicer. Others thought this

\footnotetext{
${ }^{6}$ For the history of female textile workers and the gendered meanings of the industry, see Honig (1986) and Rofel (1999).

${ }^{7}$ Scholars have long noted the salience of transnationally circulated fashion in Muslim women's choice to veil. For instance, finding an intriguing connection between religion and capitalism through the Marxian term "commodity fetishism," Carla Jones $(2007,2010)$ has explored how the fetish built into the commodity might both buttress and interfere with the attraction of fashionable veils in facilitating Islamic piety in Indonesia. The ideology of religious devoutness, indicated by the donning of fashionable veils, reinforces through the notion of individual piety the structural concealment of the relations of production that underpin the manufacture of these sartorial items. Commodity fetishism here taps into explicitly religious values. For the articulation of fashion and piety, see also Macleod (1991, 106), Zuhur (1992, 59), Smith-Hefner (2007, 413-14), Ahmed (2011, 101, 133), Korteweg and Yurdakul (2014, 9), and Abbas (2015).
} 
was a result of "diversity" - that people can now "choose to wear whatever color they like." Of all these explanations, one stands out as particularly intriguing, not because it offers the definitive answer but because it bears a distinct mark of the new era of market economy: some women suggested that the maozi were dyed a light blue because some manufacturers had to find a way to dispose of excess blue pigment that could not be consumed in the production process. "They needed to use it up, so they dipped the maozi in it. They did not think much. But when the maozi came out, everyone liked them. They were sold out immediately. So now everyone wears a blue maozi rather than a white one," a Hui woman in her midthirties told me. The waste is recycled, and the result, miraculously, is even more profitable than the original. One could hardly think of a better note on the unpredictability and uncertainty-hence risk, adventure, and quick money-presented by an emerging and amorphous market.

However, this fabulous story still cannot explain why the blue went through different shades, particularly why lavender blue was suddenly replaced by a much darker Egyptian blue, which was only gradually lightened for later maozi. "White maozi makes your face look darker, while dark blue makes your face look whiter," a middle-aged Hui woman answered my question succinctly. But the issue of complexion reaches far deeper than a fashion preference. The neoliberal reform did not produce a complete reconfiguration of the gendered division of labor in rural northwest China. If anything, it largely perpetuated the old structure: rather than being sent off by their collectives, men now move voluntarily as migrant workers into the city, leaving their aged parents and young children behind. ${ }^{8}$ Women again become the major (sometimes only) workforce in rural agriculture-men come and go, but women appear to be literally "earthbound" (Fei and Zhang 1948).

In the Wuzhong countryside where Mayi lives, and more generally in northwest China, the reallocation of farmland for industrial development and the aggressive New Rural Construction (xinnongcun jianshe) project since the early 2000s, both vital for the local government in its attempts to generate revenue, entail a specific consequence for women. Since the amount of land left for each individual household decreased considerably, the income-if any - from agriculture hardly figures prominently in the family budget. Men (except those in their sixties and seventies) rarely waste their energy on the family land, and plowing and harvesting are left largely to women. This general economic shift has produced a further division among the rural women

\footnotetext{
${ }^{8}$ This is not to deny that in certain regions of China, it was women rather than men who initiated labor migration both in the socialist and in the reform periods. See Yan $(2003,2008)$.
} 
as well: some families with adjoining plots would rent their land to a single family to be cultivated by the women of that household, occasionally without asking for any payment. Those "liberated" from agricultural labor normally work odds-and-ends jobs in the nearby town or the nearest city. Many of them rarely leave their own province, and even if they work alongside their husbands on construction sites (a common temporary occupation among migrant workers), they tend to be treated as xiaggong ("minor workers"), paid much less and assigned jobs considered unskilled, though not necessarily physically less demanding. ${ }^{9}$ To look whiter in this context is to convey the idealistic message that one has been removed from backbreaking manual labor under the scorching sun. A dark blue maozi could help to deny at the level of representation what continues to remain undeniable at the level of daily production.

For those Hui women who are indeed left behind to shoulder the burden of agricultural labor, another factor specific to northwest China aggravates their situation. Draught is the climatic norm for a large part of this vast area. In southern Ningxia, which is five hours' drive from where Mayi lives, low precipitation rates and rapid vaporization force the local Hui peasants to come up with innovative ways to save water. In addition to drilling deep wells, many families dig underground vaults (shuijiao) to store snow and rainwater. The walls of the chamber are often covered by local waterproof clay. "We leave the water set so the manures and grass will slowly sediment. Then we drink from the top," a Hui woman told me. A family can hardly get by with this water. The performance of the five daily prayers and other Islamic rituals require a steady supply of fresh water, while drinking and irrigation are necessary for mere survival. In this daily struggle to save and use water most efficiently, a mother-in-law would not enjoy seeing her young daughter-in-law wash her maozi on a daily basis. "A white maozi gets dirty easily, while dark blue can conceal the sweat marks and you don't need to wash it every day," was a common reply I received from married Hui women during my fieldwork (fig. 5).

Over the years the color of the maozi has continued to change, taking unexpected turns that can nonetheless be linked to labor. Women's admiration for nurses (who in China wear pink hats with their uniforms) - their professionalism, cleanliness, their supposedly quintessentially feminine job in an environment far removed from agricultural labor-led them in the 2000s to prefer maozi with a light pinkish color. This trend was reinforced after a flurry of state media coverage that portrayed the altruism of nurses in the aftermath of the severe Sichuan earthquake in 2008. The pink maozi became

\footnotetext{
${ }^{9}$ I thank Will Thomson for bringing this to my attention.
} 


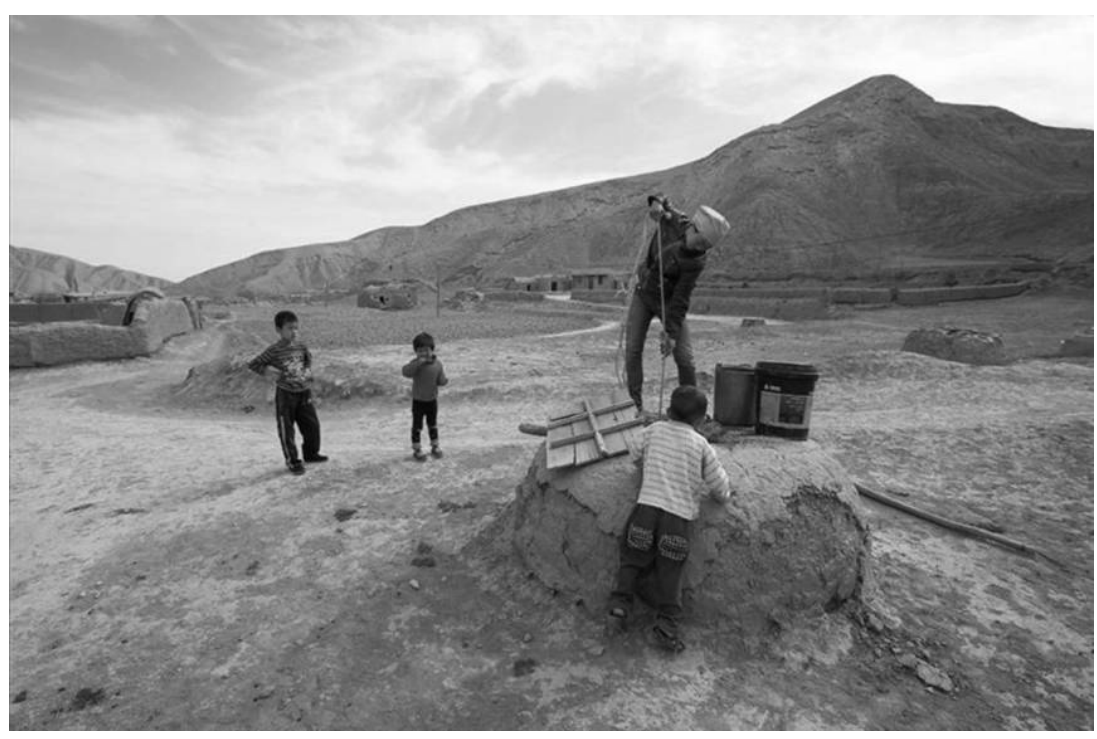

Figure 5 A Hui Muslim woman lifting water from shuijiao in Tongxin, Ningxia, 2015. Courtesy of Ma Xiaofeng. A color version of this figure is available online.

a medium through which the manual labor of many Hui Muslim women could be represented and reimagined as similar to that performed by the nurses, considered now to be feminine prototypes. Although contemporary maozi continue to be made from polyester, the fabric has become much more durable, and in contrast to earlier versions, maozi worn by current Hui women retain their cylindrical shape even after numerous machine washes, as the washing machine gradually finds its way into some rural Hui homes (see fig. 6).

Meanwhile, rapid urbanization and the loosening of control over labor migration since the 1990s have also brought many rural Hui women into the city. Their blue and pink maozi have become a distinct mark of rurality, "backwardness," and "lack of taste," not just in the eyes of non-Muslim women. When Maris Gillette wrote in 2000 about the contested adoption of skirts among Hui Muslim women in China's northwestern city of Xi'an, urban Hui women were also subject to the increasing influence of transnational Islamic fashion radiating from Saudi Arabia, Turkey, the United Emirates, and-closer to home-Malaysia (209-10). Gaitou, rather than merely an indication of piety or modesty, becomes a fashion statement and a figure of one's class status, while maozi, despite its changes throughout the years, appears too familiar, too predictable - even a little hideous for some urban Hui Muslim women. "You see, these young Hui women. They look quite fashionable, but the maozi is a giveaway," a middle-class Hui woman once 


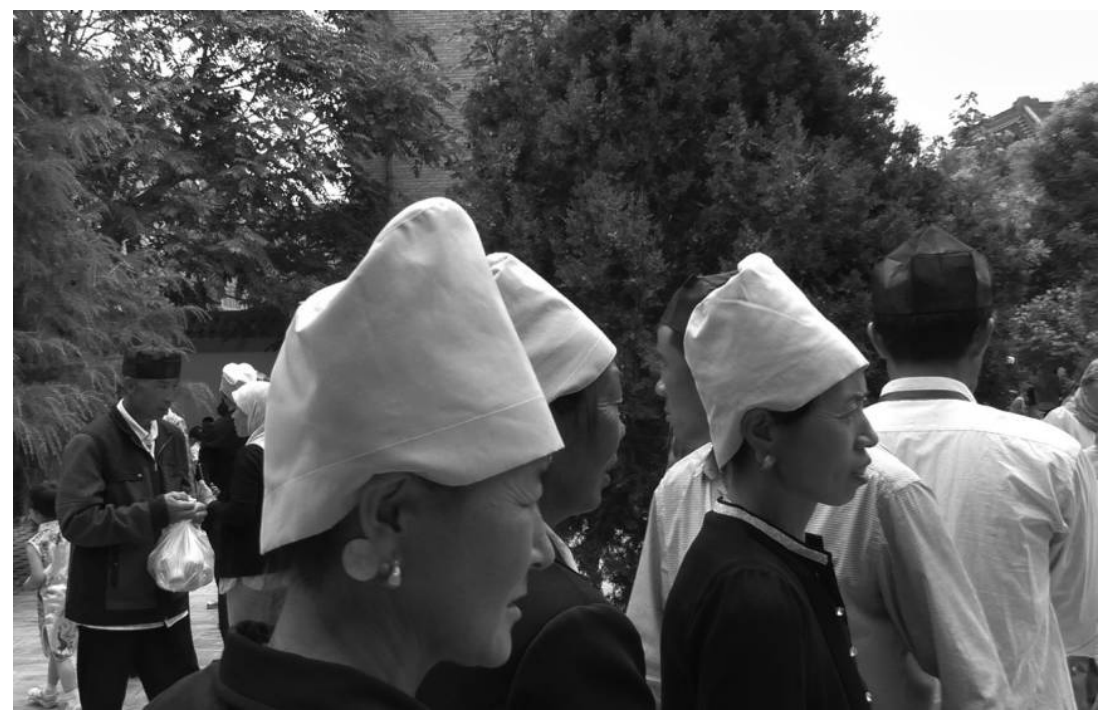

Figure 6 The pink maozi, in Zhangjiachuan, Gansu Province, northwest China. Photo by the author. July 12, 2015. A color version of this figure is available online.

remarked to me, while pointing at a maozi-wearing woman dressed in a pair of UGG boots. Perhaps not surprising, the structural link between urban women textile workers and rural Hui women has been severed and superseded by a transnational network of consumption that aggravates the growing schism separating urban women from their rural sisters.

\section{Conclusion}

In this article, rather than taking maozi as a point of departure for posing questions about piety and ethical self-cultivation, I have used it as a diagnostic of the impact of transnational political economy on rural Hui Muslim women in northwest China. In making this shift, I have followed the analytical approach proposed by Lila Abu-Lughod in 1990. While she took the specific form and location of resistance as a diagnostic of complex workings of power, thus criticizing what she dubbed the "romance of resistance" (Abu-Lughod 1990; see also 2013), in this article I have tried to use the shifting materialities of the maozi and their articulation in transnational political economy to question what might be called the romance of ethical selfcultivation that results from the broad application of Saba Mahmood's argument in contemporary studies of Muslim women around the world.

The ethnography of maozi shows that either in the socialist or the neoliberal period, this particular item of women's clothing always invokes the spe- 
cific relations of labor that embrace it: laobaibu ("old white cloth") points to women's domestic labor of weaving and spinning; the bleached white diqueliang ("truly cool") is a product of the socialist articulation of female labor power across the rural-urban divide and provides the conditions for rural Hui women to reimagine their agricultural labor in line with that of the urban proletarian; the different shades of blue given to the maozi in the neoliberal period bespeak the new configuration of labor relations (reapportioning and fragmentation of land, women as the major agricultural workforce, and their marginal position in construction work, to name just a few) that offers few possibilities of politico-economic well-being; and the more recent pink maozi, in its invocation of the nonagricultural and professional occupation of the female nurse, expresses many rural Hui women's desire to break free from onerous field labor and achieve upward social mobility. At a time when many rural Muslim women are forced by circumstances to remain bound to agriculture, the maozi has perhaps become a particularly significant site for condensing and expressing their desire for a different life.

We also need to pay attention to how these Hui women narrate their own stories. As I have mentioned, maozi seldom elicits a conversation on piety or self-cultivation: my interlocutors are much less interested in telling me why they wear the maozi than they are in recounting to me what specific changes the maozi has undergone in recent history. They rarely dwell on their attitude toward veiling or offer me their opinion on piety and feminine virtue. My initial attempt at using maozi to broach interviews on the ethical practice of piety could hardly get through, while inquiries on maozi's color and fabric often led to a lively discussion. Discourses on ethical self-cultivation sometimes run the risk of being appropriated by male Islamists. ${ }^{10}$ But maozi seems to be stuck in a silent corner, outside the bustle of feminist discourses and Islamist propaganda, unable to speak up or to elicit attention. Turning to labor has enabled me to listen to its silence, to explore the relevance of this silence to the headscarf controversy, and to ground the transnational feminist concern within translational political economy. ${ }^{11}$

When the androcentric Islamist discourse shows no interest in the maozi, when urban hijāa-wearing and fashion-loving women accuse the maozi of being a sign of rural backwardness and customary practice irrelevant - even antithetical — to Islam, when we struggle to dispute Islamophobia by arguing that women can indeed acquire agency by inhabiting rather than resisting the

${ }^{10}$ For male Islamist appropriation of the veil and its interpretations, see Smith-Hefner (2007, 413-14), Weber (2012), and Ibrahimhakkioglu (2013).

${ }^{11}$ I am deeply indebted to Gayatri Chakravorty Spivak $(1988,1989)$ for this shift of perspective. 
patriarchal norm, maozi continues to remain silent among the Hui Muslim women in rural northwest China. Or perhaps it has never been silent. In order to render its voice audible and its story comprehensible, we need to link the transnational articulation of difference and the transnational organization of ethical practice to the transnational distribution of values and materialities, as I have tried to achieve in this article. The notion of ethical self-cultivation is an invitation to rethink the intrinsic link between global Islamism and global political economy. This may be the most profound theoretical challenge that maozi sets before us.

Department of Music

SOAS, University of London

\section{References}

Abbas, Saba. 2015. “'My Veil Makes Me Beautiful': Paradoxes of Zeena and Concealment in Amman." Iournal of Middle East Women's Studies 11(2):139-60.

Abu-Lughod, Lila. 1986. Veiled Sentiments: Honor and Poetry in a Bedouin Society. Berkeley: University of California Press.

- 1990. "The Romance of Resistance: Tracing Transformations of Power through Bedouin Women." American Ethnoloaist 17(1):41-55.

- 1993. Writing Women's Worlds: Bedouin Stories. Berkeley: University of California Press.

- 2013. Do Muslim Women Need Saving? Cambridge, MA: Harvard University Press.

Afshar, Haleh. 2008. "Can I See Your Hair? Choice, Agency and Attitudes: The Dilemma of Faith and Feminism for Muslim Women Who Cover." Ethnic and Racial Studies 31(2):411-27.

Ahmed, Leila. 2011. A Quiet Revolution: The Veil's Resurgence, from the Middle East to America. New Haven, CT: Yale University Press.

Ahmed, Sadaf. 2009. Transforming Faith: The Story of Al-Huda and Islamic Revivalism among Urban Pakistani Women. Syracuse, NY: Syracuse University Press.

Alvi, Anjum. 2013. "Concealment and Revealment: The Muslim Veil in Context." Current Anthropology 54(2):177-99.

Behiery, Valerie. 2012. "Alternative Narratives of the Veil in Contemporary Art." Comparatipe Studies of South Asia, Africa, and the Middle East 32(1):130-46.

Bowen, John Richard. 2008. Why the French Don't Like Headscarves: Islam, the State, and Public Space. Princeton, NJ: Princeton University Press.

- 2010. Can Islam Be French? Pluralism and Pragmatism in a Secularist State. Princeton, NJ: Princeton University Press.

Broomhall, Marshall. 1910. Islam in China: A Neglected Problem. London: Morgan \& Scott; China Inland Mission.

Bucar, Elizabeth. 2012. The Islamic Veil: A Beginner's Guide. Oxford: Oneworld. 
Celik, Ipek A. 2012. "Performing Veiled Women as Marketable Commodities: Representations of Muslim Minority Women in Germany." Comparative Studies of South Asia, Africa, and the Middle East 32(1):116-29.

Çınar, Alev. 2008. "Subversion and Subjugation in the Public Sphere: Secularism and the Islamic Headscarf." Signs: Iournal of Women in Culture and Societv 33 (4):891-913.

Croll, Elisabeth. 1978. Feminism and Socialism in China. London: Routledge \& Kegan Paul.

Droogsma, Rachel Anderson. 2007. "Redefining Hijab: American Muslim Women's Standpoints on Veiling." Iournal of Applied Communication Research 35 (2):294-319.

El-Guindi, Fadwa. 1999. Veil: Modestv, Privacv, and Resistance. Oxford: Berg.

Elver, Hilal. 2012. The Headscarf Controversy: Secularism and Freedom of Religion. Oxford: Oxford University Press.

Fei Xiaotong. 1939. Peasant Life in China: A Field Study of Country Life in the Yangtze Valley. London: George Routledge \& Sons.

- 1953. China's Gentry: Essays in Rural-Urban Relations. Chicago: University of Chicago Press.

Fei Xiaotong and Zhiyi Zhang. 1948. Earthbound China: A Study of Rural Economy in Yunnan. London: Routledge \& Kegan Paul.

Gabriel, Theodore, and Rabiha Hannan, eds. 2011. Islam and the Veil: Theoretical and Regional Contexts. London: Continuum.

Gillette, Maris B. 2000. Between Mecca and Beijing: Modernization and Consumption among Urban Chinese Muslims. Stanford, CA: Stanford University Press.

Gökarıksel, Banu, and Anna Secor. 2014. "The Veil, Desire, and the Gaze: Turning the Inside Out." Signs 40(1):177-200.

Heath, Jennifer, ed. 2008. The Veil: Women Writers on Its History, Lore, and Politics. Berkeley: University of California Press.

Hershatter, Gail. 2011. The Gender of Memory: Rural Women and China's Collective Past. Berkeley: University of California Press.

Honig, Emily. 1986. Sisters and Strangers: Women in the Shanghai Cotton Mills, 1919-1949. Stanford, CA: Stanford University Press.

Ibrahimhakkioglu, Fulden. 2013. "Beyond the Modern/Religious Dichotomy: The Veil and Feminist Solidarity in Contemporary Turkey." Philosophical Topics 41 (2):141-56.

Jamal, Amina. 2013. Jamaat-e-Islami Women in Pakistan: Vanguard of a New Modernity? Syracuse, NY: Syracuse University Press.

Jones, Carla. 2007. "Fashion and Faith in Urban Indonesia." Fashion Theorv $11(2 / 3)$ : 211-32.

- 2010. "Images of Desire: Creating Virtue and Value in an Indonesian Islamic Lifestyle Magazine." Iournal of Middle Eastern Women's Studies 6(3): 91-117.

Keane, Webb. 2007. Christian Moderns: Freedom and Fetish in the Mission Encounter. Berkeley: University of California Press. 
2013. "On Spirit Writing: Materialities of Language and the Religious Work of Transduction." Iournal of the Roval Anthropological Institute 19(1):1-17.

Killian, Caitlin. 2003. "The Other Side of the Veil: North African Women in France Respond to the Headscarf Affair." Gender and Societv 17(4):567-90.

Korteweg, Anna C., and Gökçe Yurdakul. 2014. The Headscarf Debates: Conflicts of National Belonging. Stanford, CA: Stanford University Press.

Macleod, Arlene Elowe. 1991. Accommodating Protest: Working Women, the New Veiling, and Change in Cairo. New York: Columbia University Press.

_. 1992. "Hegemonic Relations and Gender Resistance: The New Veiling as Accommodating Protest in Cairo." Siqns 17(3):533-57.

Mahmood, Saba. 2001. "Feminist Theory, Embodiment, and the Docile Agent: Some Reflections on the Egyptian Islamic Revival." Cultural Anthropologr 16 (2):202-36.

2005. Politics of Piety: The Islamic Revival and the Feminist Subject. Princeton, NJ: Princeton University Press.

Mott, John R., Harlan P. Beach, and Samuel Zwemer. 1910. "Introductory Preface." In Broomhall 1910, ix-x.

O’Neill, Brenda, Elisabeth Gidengil, Catherine Côté, and Lisa Young. 2014. "Freedom of Religion, Women's Agency, and Banning the Face Veil: The Role of Feminist Beliefs in Shaping Women's Opinion.” Ethnic and Racial Studies 38 (11):1886-1901.

Özcan, Esra. 2013. "Lingerie, Bikinis, and the Headscarf: Visual Depictions of Muslim Female Migrants in German News Media." Feminist Media Studies 13 (3):427-42.

Rofel, Lisa. 1999. Other Modernities: Gendered Yearninas in China after Socialism. Berkeley: University of California Press.

Ruby, Tabassum F. 2006. "Listening to the Voices of Hijab." Women's Studies International Forum 29(1):54-66.

Scott, Joan Wallach. 2007. The Politics of the Veil. Princeton, NJ: Princeton University Press.

Selby, Jennifer A. 2014. “Un/veiling Women's Bodies: Secularism and Sexuality in Full-Face Veil Prohibitions in France and Quebec." Studies in Religion/Sciences Religieuses 43(3):439-66.

Selim, Samah. 2010. "Politics of Piety: The Islamic Revival and the Feminist Subject.” Jadaliyya, http://www.jadaliyya.com/pages/index/235/book-review _politics-of-piety_the-islamic-revival-.

Smith-Hefner, Nancy J. 2007. "Javanese Women and the Veil in Post-Soeharto Indonesia." Iournal of Asian Studies 66(2):389-420.

Spivak, Gayatri Chakravorty. 1988. "Can the Subaltern Speak?” In Marxism and the Interpretation of Culture, ed. Cary Nelson and Lawrence Grossberg, 271-313. Urbana: University of Illinois Press.

1989. "The Political Economy of Women as Seen by a Literary Critic." In Coming to Terms: Feminism, Theory, Politics, ed. Elizabeth Weed, 218-29. New York: Routledge. 
Stehle, Maria. 2012. "Gender, Performance, and the Politics of Space: Germany and the Veil in Popular Culture." Comparative Studies of South Asia, Africa, and the Middle East 32(1):89-101.

Taylor, Pamela. 2008. "I Just Want to Be Me: Issues in Identity for One American Muslim Woman." In The Veil: Women Writers on Its History, Lore, and Politics, ed. Jennifer Heath, 119-36. Berkeley: University of California Press.

Weber, Beverly M. 2012. "Hijab Martyrdom, Headscarf Debates: Rethinking Violence, Secularism, and Islam in Germany." Comparative Studies of South Asia. Africa, and the Middle East 32(1):102-15.

Wilson, J. Christy. 1952. Apostle to Islam: A Biography of Samuel M. Zwemer. Grand Rapids, MI: Baker.

Yan Hairong. 2003. "Spectralization of the Rural: Reinterpreting the Labor Mobility of Rural Young Women in Post-Mao China." American Ethnoloaist 30(4): 57896.

2008. New Masters, New Servants: Migration, Development, and Women Workers in China. Durham, NC: Duke University Press.

Zuhur, Sherifa. 1992. Revealing Reveiling: Islamist Gender Ideology in Contemporary Egypt. Albany, NY: SUNY Press. 